\title{
Pediococcus stilesii sp. nov., isolated from maize grains
}

Charles M. A. P. Franz, ${ }^{1}$ Marc Vancanneyt, ${ }^{2}$ Katrien Vandemeulebroecke, ${ }^{2}$ Marjan De Wachter, ${ }^{2}$ Ilse Cleenwerck, ${ }^{2}$ Bart Hoste, ${ }^{2}$ Ulrich Schillinger, ${ }^{1}$ Wilhelm H. Holzapfel ${ }^{1}$ and Jean Swings ${ }^{2}$

Correspondence Charles M. A. P. Franz Charles.Franz@bfe.unikarlsruhe.de

\author{
${ }^{1}$ Federal Research Centre for Nutrition and Food, Institute for Hygiene and Toxicology, \\ Haid-und-Neu-Strasse 9, D-76131 Karlsruhe, Germany \\ ${ }^{2}$ BCCM/LMG Bacteria Collection, Laboratory of Microbiology, Ghent University, \\ Ledeganckstraat 35, B-9000 Ghent, Belgium
}

\begin{abstract}
A Gram-positive, coccus-shaped, lactic acid bacterium, strain LMG $23082^{\top}$, was isolated from steeped maize grains. The organism is homofermentative and produces $D$ - and L-lactic acid from glucose. 16S rRNA gene sequence analysis revealed that the organism belongs to the genus Pediococcus, with Pediococcus pentosaceus and Pediococcus acidilactici as nearest neighbours. Genotypic fingerprinting, whole-cell protein electrophoresis, DNA-DNA hybridizations and physiological and biochemical tests allowed differentiation of strain LMG $23082^{\top}$ from other established Pediococcus species. A remarkable feature was that, unlike other pediococci, this bacterium was capable of growth at $\mathrm{pH} 9 \cdot 0$. The strain studied represents a novel species for which the name Pediococcus stilesii sp. nov. is proposed with the type strain LMG $23082^{\top}$ (=BFE $1652^{\top}=$ FAIR-E $180^{\top}=$ CCUG $51290^{\top}$ ), the only currently known isolate of the species.
\end{abstract}

The genus Pediococcus consists of seven species at the time of writing, Pediococcus acidilactici, $P$. claussenii, $P$. damnosus, $P$. dextrinicus, $P$. inopinatus, $P$. parvulus and $P$. pentosaceus. The former [Pediococcus] urinaeequi has recently been reclassified as Aerococcus urinaeequi on the basis of $16 \mathrm{~S}$ rRNA gene sequencing and DNA-DNA hybridizations (Felis et al., 2005). Based on the phylogeny, P. dextrinicus is distantly related to the other pediococci (Dobson et al., 2002) and is also phenotypically distinguished from other Pediococcus species by the combination of the production of $\mathrm{L}(+)$ lactate as the end product of glucose metabolism and the production of $\mathrm{CO}_{2}$ from gluconate (Back, 1978; Simpson \& Taguchi, 1995). Although P. dextrinicus is still a member of the genus, it has been suggested that it should be reclassified in the genus Lactobacillus (Collins et al., 1990; Dobson et al., 2002). In the present study, we describe a novel Pediococcus species, isolated from steeped white maize grains.

Strain LMG $23082^{\mathrm{T}}\left(=\mathrm{BFE} 1652^{\mathrm{T}}=\right.$ FAIR-E $\left.180^{\mathrm{T}}\right)$ was isolated in 1997 in Lagos, Nigeria, from white maize grains,

Published online ahead of print on 23 September 2005 as DOI 10.1099/ijs.0.63944-0.

Abbreviation: FAFLP, fluorescent amplified fragment length polymorphism.

The GenBank/EMBL/DDBJ accession number for the 16S rRNA gene sequence of LMG $23082^{\top}$ is AJ973157. steeped for 3 days. Isolation and purification conditions were MRS agar (de Man et al., 1960) at $30^{\circ} \mathrm{C}$ under aerobic conditions. Analogous cultivation conditions were used for further experiments, unless indicated otherwise.

Cell morphology was determined using phase-contrast microscopy. Cells of strain LMG $23082^{\mathrm{T}}$ were cocci, with a cell diameter of $1 \cdot 2 \mu \mathrm{m}$. Cells occurred singly, in pairs or tetrads, the latter being typical for pediococci as a result of dividing alternately in two perpendicular directions (Simpson \& Taguchi, 1995).

The phylogenetic position of strain LMG $23082^{\mathrm{T}}$ was determined by complete $16 \mathrm{~S}$ rRNA gene sequence analysis as described by Vancanneyt et al. (2004) with the following modifications: PCR-amplified 16S rDNA was purified by using a NucleoFast 96 PCR Clean-up kit (Macherey-Nagel). Sequencing reactions were purified using a Montage SEQ $_{96}$ Sequencing Reaction Clean-up kit (Millipore). Sample preparation was assisted using a Tecan Genesis Workstation 200 (Tecan). Electrophoresis of sequence reaction products was performed by using an ABI Prism 3100 Genetic Analyzer (Applied Biosystems). The 16S rRNA gene sequence (a continuous stretch of $1529 \mathrm{bp}$ ) and sequences of other pediococci, as well as Lactobacillus species belonging to the Lactobacillus/Pediococcus phylogenetic group which were retrieved from EMBL, were aligned and a phylogenetic tree was constructed by the neighbourjoining method using the BioNumerics software package, 


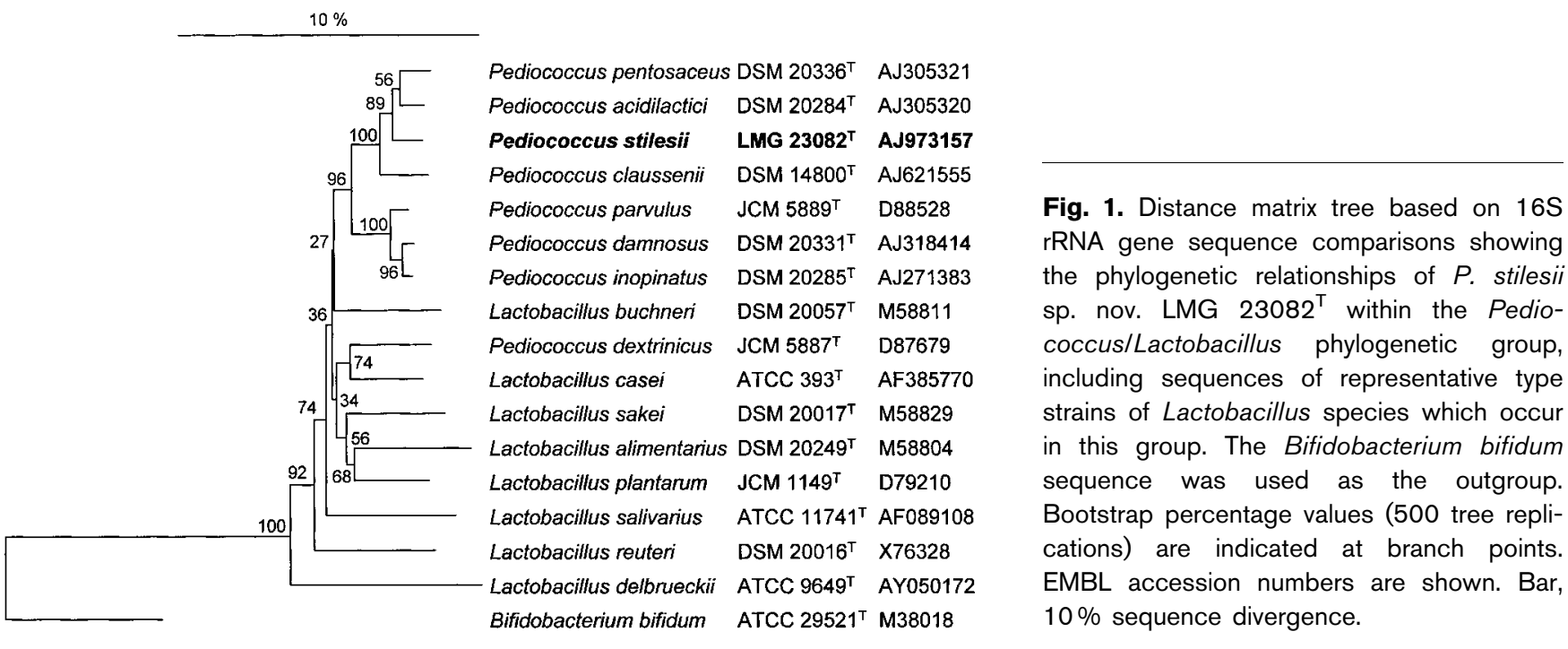

version 3.50 (Applied Maths). Unknown bases were discarded for the analyses. Bootstrapping analysis was undertaken to test the statistical reliability of the topology of the neighbour-joining tree using 500 bootstrap resamplings of the data (Fig. 1). Comparison of the sequence of strain LMG $23082^{\mathrm{T}}$ with deposited sequences available in the EMBL database revealed highest similarities with $P$. pentosaceus and $P$. acidilactici (sequence similarities of $98 \cdot 2$ and $97 \cdot 5 \%$, respectively). Within the genus Pediococcus, the latter two taxa and $P$. claussenii occupy a distinct branch.

Strains of all recognized Pediococcus species were screened using SDS-PAGE of whole-cell proteins. Whole-cell protein extracts were prepared and SDS-PAGE was performed as described by Pot et al. (1994). Densitometric analysis, normalization and interpolation of protein profiles, and a numerical analysis were performed by using the GelCompar software package, versions 3.1 and 4.0, respectively (Applied Maths). A dendrogram confirmed that LMG $23082^{\mathrm{T}}$ constitutes a separate branch, distinct from its nearest phylogenetic neighbours, $P$. pentosaceus and P. acidilactici (Fig. 2).

Because of its higher taxonomic resolution compared with SDS-PAGE of proteins (Gancheva et al., 1999; Torriani et al., 2001), pediococcal reference strains and LMG $23082^{\mathrm{T}}$ were also investigated using fluorescent amplified-fragment length polymorphism (FAFLP) fingerprinting of whole genomes. FAFLP fingerprinting was performed as described by Thompson et al. (2001) with the following modifications: EcoRI/ TaqI was used as the restriction enzyme combination and the primer combination E01/T01 (both having an adenosine extension at the 3 '-end) was applied for selective PCR. The resulting electrophoretic patterns were tracked and normalized using the GeneScan 3.1 software (Applera). Normalized tables of peaks, containing fragments of 50-536 bp, were transferred into the BioNumerics software package, version 3.5, and the computer-generated fingerprints were added to an existing database of FAFLP fingerprints of lactic acid bacteria at the BCCM/LMG Bacteria Collection. For numerical analysis, data between the 75- and 500-bp bands of the internal standard were used. Similarity was calculated using the Dice coefficient and clustering was done using the UPGMA algorithm. The FAFLP fingerprints of all strains were compared with reference profiles of lactic acid bacteria taxa as currently available in the database. FAFLP analysis revealed a separate branch for strain LMG $23082^{\mathrm{T}}$ (Fig. 3).

As a further genotypic approach, rep-PCR was conducted using the primer (GTG) 5 (5'-GTGGTGGTGGTGGTG-3') following the method described by Gevers et al. (2001) for lactic acid bacteria. Total genomic DNA was isolated from the type strains of all recognized Pediococcus species according to the method of Pitcher et al. (1989), as modified by Björkroth \& Korkeala (1996), relying on a combined lysozyme and mutanolysin treatment. DNA was amplified in $50 \mu \mathrm{l}$ volumes containing $100 \mathrm{ng}$ template DNA, $1 \times$ Taq DNA polymerase buffer (Amersham Pharmacia), $200 \mu \mathrm{M}$ dNTPs, $50 \mathrm{pM}$ primer, $4 \%$ DMSO (Sigma) and $1.5 \mathrm{U}$ Taq DNA polymerase (Amersham Pharmacia). PCR products were separated by electrophoresis and images were visualized and analysed as described by Kostinek et al. (2005) using the BioNumerics (version 2.5) software (Applied Maths). Groupings of the rep-PCR fingerprints were performed by using the Pearson productmoment correlation coefficient $(r)$ and the UPGMA clustering algorithm (Sneath \& Sokal, 1973). Using repPCR, LMG $23082^{\mathrm{T}}$ was clearly distinguished from the other type strains and had the closest, although not significant, match with $P$. inopinatus at a correlation level of $r=0.61$ (Fig. 4). It is not known whether the (GTG) $)_{5}$ sequence, which is highly repetitive on the chromosome of Escherichia coli (Versalovic et al., 1994) is indeed present and, if so, how often it would be present in the genomes of pediococci. Nevertheless, even if we assume that it is not, the resolution of the method would resemble a RAPD-PCR-type genotyping method. Therefore, in our study, as in the study of 
$r(\%)$

60708090100

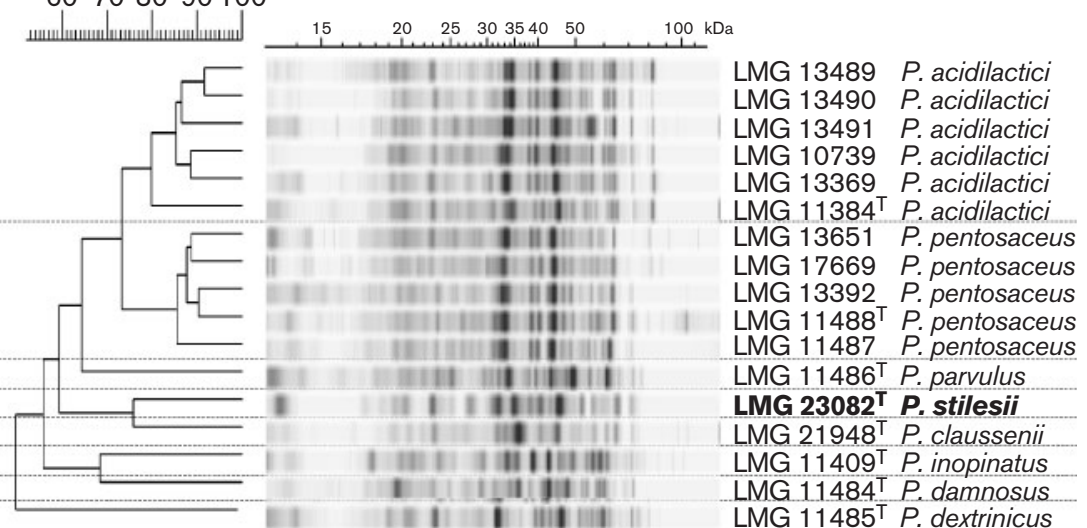

Fig. 2. Protein profiles and corresponding dendrogram, derived from UPGMA linkage of correlation coefficients ( $r$, expressed as a percentage value for convenience), of $P$. stilesii and other representative pediococci.
Gevers et al. (2001), the method was clearly suitable to discriminate among the pediococci at the species level.

For determination of the DNA base composition and DNADNA binding values, DNA was isolated from strains LMG $23082^{\mathrm{T}}, P$. pentosaceus LMG $11488^{\mathrm{T}}$ and $P$. acidilactici LMG $11384^{\mathrm{T}}$ and purified according to the method of Marmur (1961) as modified by Stackebrandt \& Kandler (1979). The DNA base composition ( $\mathrm{G}+\mathrm{C}$ content) was determined from the thermal melting temperature $\left(T_{\mathrm{m}}\right)$ of DNA using a spectrophotometer (Varian Cary 100 Bio UV-Visible). DNA-DNA relatedness was determined spectrophotometrically from renaturation rates according to De Ley et al. (1970). DNA from LMG $23082^{\mathrm{T}}$ was hybridized with DNA of $P$. pentosaceus LMG $11488^{\mathrm{T}}$ and $P$. acidilactici LMG $11384^{\mathrm{T}}$. A low reassociation value of $14 \cdot 5 \%$ was obtained with the type strain of $P$. acidilactici and $21 \%$ with the type strain of $P$. pentosaceus, values that were well below the recommended $70 \%$ cut-off value that indicates separate species (Wayne et al., 1987). The DNA G + C content of LMG $23082^{\mathrm{T}}$ was $38 \cdot 0 \mathrm{~mol} \%$.

Phenotypic characterization was performed according to Schillinger \& Lücke (1987). D(-)- and L(+)-lactate were determined from culture supernatants after $48 \mathrm{~h}$ of growth using an enzyme test kit (Roche Diagnostics). Maximum $\mathrm{pH}$ and $\mathrm{NaCl}$ tolerance were determined in MRS broth (Merck) after aerobic incubation for 5 days at $37^{\circ} \mathrm{C}$. The API 50 CHL identification system (bioMérieux) was used to determine the carbohydrate fermentation profile. Biochemical tests results are summarized in Table 1 and given in the species description below. LMG $23082^{\mathrm{T}}$ is distinguished from $P$. pentosaceus by its inability to produce acid from arabinose and lactose, from $P$. acidilactici by its inability to ferment xylose, and from $P$. claussenii by its ability to produce acid from galactose and DL-lactate from glucose (Table 1). Acid production from ribose distinguishes LMG $23082^{\mathrm{T}}$ from $P$. damnosus, $P$. inopinatus and $P$. parvulus. Unlike other pediococci, LMG $23082^{\mathrm{T}}$ grew at pH 9.0 (Table 1) and even at pH 9.6 (result not shown), a phenotypic characteristic which is commonly used to distinguish pediococci, lactococci and streptococci from enterococci (Weiss, 1991; Hardie \& Whiley, 1997). The physiological and ecological significance of this alkaliphilic trait is not known, especially when considering that only one strain was isolated, which makes interpretations of such properties difficult. The maximum $\mathrm{NaCl}$ concentration for growth after 5 days of incubation was $8 \%$, a value which is higher than those reported for $P$. claussenii (5\%), $P$. damnosus (5\%) and $P$. dextrinicus $(6 \%)$, but lower than

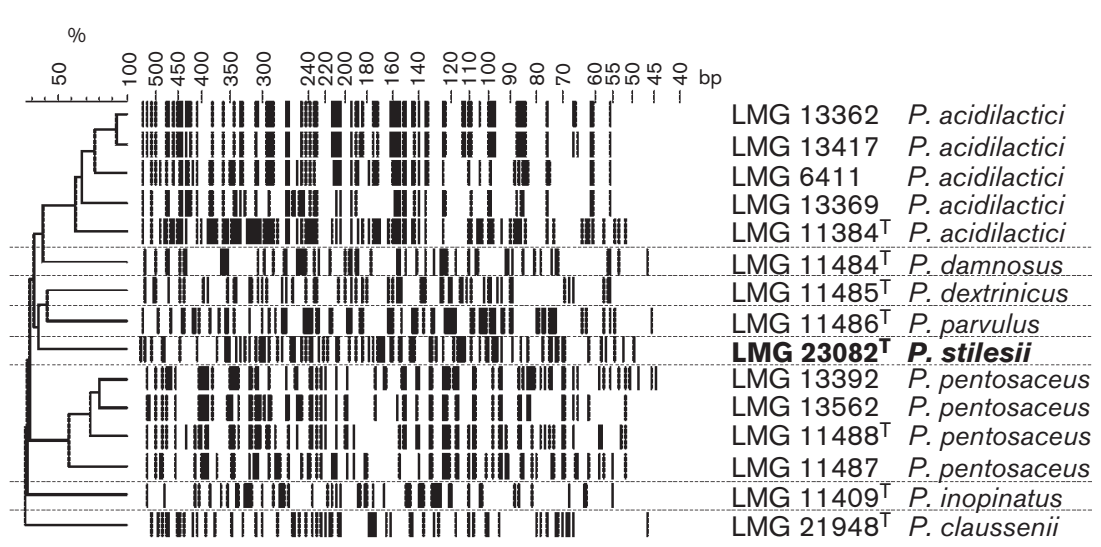

Fig. 3. FAFLP patterns and corresponding dendrogram, derived from the UPGMA linkage of Dice coefficients (expressed as a percentage value for convenience), of $P$. stilesii and other representative pediococci. 


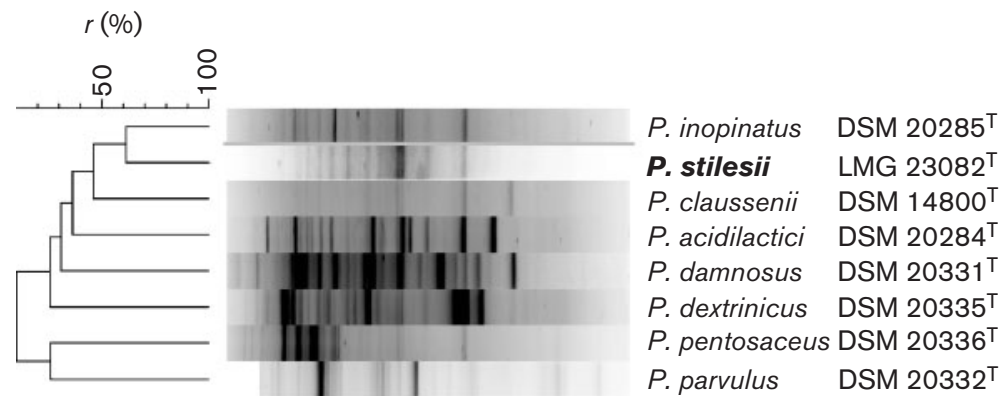

Fig. 4. (GTG $)_{5}-P C R$ fingerprints and corresponding dendrogram, derived from UPGMA linkage of correlation coefficients ( $r$, expressed as a percentage value for convenience), of $P$. stilesii and other representative pediococci.

those for $P$. pentosaceus $(10 \%)$ and $P$. acidilactici $(10 \%)$ (Simpson \& Taguchi, 1995; Holzapfel et al., 2005).

All results obtained in the present study allowed us to assign strain LMG $23082^{\mathrm{T}}$ to a novel species, for which we propose the name Pediococcus stilesii sp. nov.

\section{Description of Pediococcus stilesii sp. nov.}

Pediococcus stilesii (stile'si.i. N.L. gen. n. stilesii named in honour of Prof. emerit. Michael E. Stiles, a food microbiologist who specialized in food preservation with bacteriocinogenic lactic acid bacteria).
Cells are cocci, $0 \cdot 6-1 \cdot 2 \mu \mathrm{m}$ in diameter. They are Grampositive, non-motile, do not form spores and occur singly, in pairs or in tetrads. Colonies are white, smooth and circular with a convex elevation and an entire margin. Acid is produced from glucose, ribose, galactose, fructose, mannose, $\mathrm{N}$-acetylglucosamine, amygdalin, arbutin, aesculin, salicin, cellobiose, maltose, gentiobiose and tagatose. Acid is not produced from glycerol, erythritol, D-arabinose, L-arabinose, D-xylose, L-xylose, adonitol, methyl $\beta$-Dxylopyranoside, sorbose, rhamnose, dulcitol, inositol, mannitol, sorbitol, methyl $\alpha$-D-mannopyranoside, methyl $\alpha$-D-glucopyranoside, lactose, melibiose, sucrose, trehalose, inulin, melezitose, raffinose, starch, glycogen, xylitol,

Table 1. Phenotypic differentiating features of Pediococcus species

Species: 1, P. acidilactici; 2, P. pentosaceus; 3, P. claussenii; 4, P. damnosus; 5, P. dextrinicus; 6, P. inopinatus; 7, P. parvulus; 8, P. stilesii LMG $23082^{\mathrm{T}}$. Data partially adapted from Simpson \& Taguchi (1995) and Holzapfel et al. (2005). +, $90 \%$ or more strains positive; -, $90 \%$ or more strains negative; d, $11-89 \%$ of strains positive.

\begin{tabular}{|c|c|c|c|c|c|c|c|c|}
\hline Characteristic & 1 & 2 & 3 & 4 & 5 & 6 & 7 & 8 \\
\hline \multicolumn{9}{|l|}{ Growth at: } \\
\hline $\mathrm{pH} 4 \cdot 5$ & + & + & + & + & - & + & + & + \\
\hline $\mathrm{pH} 7 \cdot 0$ & + & + & $+^{*}$ & - & + & $\mathrm{d}$ & $\mathrm{d}$ & + \\
\hline $\mathrm{pH} 8 \cdot 0$ & + & + & $+^{*}$ & - & + & - & - & + \\
\hline $\mathrm{pH} 9 \cdot 0$ & - & - & - & - & - & - & - & + \\
\hline $35^{\circ} \mathrm{C}$ & + & + & + & - & + & + & + & + \\
\hline $40^{\circ} \mathrm{C}$ & + & $\mathrm{d}$ & $+^{\star}$ & - & + & $\mathrm{d}$ & - & + \\
\hline $45^{\circ} \mathrm{C}$ & + & $\mathrm{d}$ & - & - & - & - & - & + \\
\hline $48^{\circ} \mathrm{C}$ & + & - & - & - & - & - & - & - \\
\hline Maximum $\mathrm{NaCl}$ concentration for growth & 10 & 10 & 5 & 5 & 6 & 8 & 8 & 8 \\
\hline Lactic acid configuration & DL & DL & $\mathrm{L}(+)^{*}$ & DL & $\mathrm{L}(+)$ & DL & DL & DL \\
\hline \multicolumn{9}{|l|}{ Acid from: } \\
\hline Arabinose & $\mathrm{d}$ & + & - & - & - & - & - & - \\
\hline Galactose & + & + & - & + & $\mathrm{d}$ & + & $\mathrm{d}$ & + \\
\hline Lactose & $\mathrm{d}$ & + & - & - & $\mathrm{d}$ & + & - & - \\
\hline Melezitose & - & - & - & $\mathrm{d}$ & - & - & - & - \\
\hline Maltose & - & + & $\mathrm{d}$ & $\mathrm{d}$ & + & + & $\mathrm{d}$ & + \\
\hline Ribose & + & + & + & - & - & - & - & + \\
\hline Xylose & + & $\mathrm{d}$ & - & - & - & - & - & - \\
\hline $\mathrm{G}+\mathrm{C}$ content of DNA $(\mathrm{mol} \%)$ & 42 & 38 & $40 \cdot 5$ & $38 \cdot 5$ & $40-41$ & $39 \cdot 5$ & 41 & $38 \cdot 0$ \\
\hline
\end{tabular}

${ }^{\star}$ Data obtained for the type strain only. 
turanose, lyxose, D-fucose, L-fucose, D-arabitol, L-arabitol, potassium gluconate, potassium 2-ketogluconate or potassium 5-ketogluconate. The $\mathrm{G}+\mathrm{C}$ content of the DNA is $38 \cdot 0 \mathrm{~mol} \%$.

The type strain is LMG $23082^{\mathrm{T}}\left(=\mathrm{BFE} 1652^{\mathrm{T}}=\right.$ FAIR-E $180^{\mathrm{T}}=$ CCUG $51290^{\mathrm{T}}$ ), isolated from white maize grains.

\section{Acknowledgements}

This research was supported by the Prime Minister's Services - Federal Office for Scientific, Technical and Cultural Affairs, Belgium. The authors would like to thank Ingrid Specht and Dirk Vogel for excellent technical assistance.

\section{References}

Back, W. (1978). Elevation of Pediococcus cerevisiae subsp. dextrinicus Coster and White to species status Pediococcus dextrinicus (Coster and White) comb. nov. Int J Syst Bacteriol 28, 523-527.

Björkroth, J. \& Korkeala, H. (1996). Evaluation of Lactobacillus sake contamination in vacuum-packaged sliced cooked meat products by ribotyping. J Food Prot 59, 398-401.

Collins, M. D., Williams, A. M. \& Wallbanks, S. (1990). The phylogeny of Aerococcus and Pediococcus as determined by $16 \mathrm{~S}$ rRNA sequence analysis: description of Tetragenococcus gen. nov. FEMS Microbiol Lett 70, 255-262.

De Ley, J., Cattoir, H. \& Reynaerts, A. (1970). The quantitative measurement of DNA hybridization from renaturation rates. Eur J Biochem 12, 133-142.

de Man, J. C., Rogosa, M. \& Sharpe, M. E. (1960). A medium for the cultivation of lactobacilli. J Appl Bacteriol 23, 130-135.

Dobson, C. M., Deneer, H., Lee, S., Hemmingsen, S., Glaze, S. \& Ziola, B. (2002). Phylogenetic analysis of the genus Pediococcus, including Pediococcus claussenii sp. nov., a novel lactic acid bacterium isolated from beer. Int J Syst Evol Microbiol 52, 2003-2010.

Felis, G. E., Torriani, S. \& Dellaglio, F. (2005). Reclassification of Pediococcus urinaeequi (ex Mees 1934) Garvie 1988, as Aerococcus urinaeequi comb. nov. Int J Syst Evol Microbiol 55, 1325-1327.

Gancheva, A., Pot, B., Vanhonacker, K., Hoste, B. \& Kersters, K. (1999). A polyphasic approach towards the identification of strains belonging to Lactobacillus acidophilus and related species. Syst Appl Microbiol 22, 573-585.

Gevers, D., Huys, G. \& Swings, J. (2001). Applicability of rep-PCR fingerprinting for identification of Lactobacillus species. FEMS Microbiol Lett 205, 31-36.

Hardie, J. M. \& Whiley, R. A. (1997). Classification and overview of the genera Streptococcus and Enterococcus. J Appl Microbiol Symp Suppl 83, 1S-11S.

Holzapfel, W. H., Franz, C. M. A. P., Ludwig, W., Back, W. \& Dicks, L. M. T. (2005). Genera Pediococcus and Tetragenococcus. In The Prokaryotes, 3rd edn, An Evolving Electronic Resource for the
Microbiological Community, release 3.15. Edited by M. Dworkin, S. Falkow, E. Rosenberg, K.-H. Schleifer \& E. Stackebrandt. New York: Springer. http://link.springer-ny.com/link/service/books/10125/ Kostinek, M., Specht, I., Edward, V. A., Schillinger, U., Hertel, C., Holzapfel, W. H. \& Franz, C. M. A. P. (2005). Diversity and technological properties of predominant lactic acid bacteria from fermented cassava used for the preparation of Gari, a traditional African food. Syst Appl Microbiol 28, 527-540.

Marmur, J. (1961). A procedure for the isolation of deoxyribonucleic acid from microorganisms. J Mol Biol 3, 208-218.

Pitcher, D. G., Saunders, N. A. \& Owen, R. J. (1989). Rapid extraction of bacterial genomic DNA with guanidium thiocyanate. Lett Appl Microbiol 8, 151-156.

Pot, B., Vandamme, P. \& Kersters, K. (1994). Analysis of electrophoretic whole-organism protein fingerprints. In Chemical Methods in Prokaryotic Systematics, pp. 493-521. Edited by M. Goodfellow \& A. G. O'Donnell. Chichester: Wiley.

Schillinger, U. \& Lücke, F.-K. (1987). Identification of lactobacilli from meat and meat products. Food Microbiol 4, 199-208.

Simpson, W. J. \& Taguchi, H. (1995). The genus Pediococcus, with notes on the genera Tetragenococcus and Aerococcus. In The Genera of Lactic Acid Bacteria, pp. 125-172. Edited by B. J. B. Wood \& W. H. Holzapfel. London: Blackie Academic \& Professional.

Sneath, P. H. A. \& Sokal, R. R. (1973). Numerical Taxonomy: the Principles and Practice of Numerical Classification. San Francisco: W. H. Freeman.

Stackebrandt, E. \& Kandler, O. (1979). Taxonomy of the genus Cellulomonas, based on phenotypic characters and deoxyribonucleic acid-deoxyribonucleic acid homology and proposal of seven neotype strains. Int J Syst Bacteriol 29, 273-282.

Thompson, F. L., Hoste, B., Vandemeulebroecke, K. \& Swings, J. (2001). Genomic diversity amongst Vibrio isolates from different sources determined by fluorescent amplified fragment length polymorphism. Syst Appl Microbiol 24, 520-538.

Torriani, S., Clementi, F., Vancanneyt, M., Hoste, B., Dellaglio, F. \& Kersters, K. (2001). Differentiation of Lactobacillus plantarum, $L$. pentosus and L. paraplantarum species by RAPD-PCR and AFLP. Syst Appl Microbiol 24, 554-560.

Vancanneyt, M., Mengaud, J., Cleenwerck, I., Hoste, B., Dawyndt, P., Degivry, M. C., Ringuet, D., Janssens, D. \& Swings, J. (2004). Reclassification of Lactobacillus kefirgranum Takizawa et al. 1994 as Lactobacillus kefiranofaciens subsp. kefirgranum subsp. nov. and emended description of L. kefiranofaciens Fujisawa et al. 1988. Int J Syst Evol Microbiol 54, 551-556.

Versalovic, J., Schneider, M., de Bruijn, F. J. \& Lupski, J. R. (1994). Genomic fingerprinting of bacteria using repetitive sequence-based polymerase chain reaction. Methods Mol Cell Biol 5, 25-40.

Wayne, L. G., Brenner, D. J., Colwell, R. R. \& 9 other authors (1987). Report of the ad hoc committee on reconciliation of approaches to bacterial systematics. Int J Syst Bacteriol 37, 463-464.

Weiss, N. (1991). The genera Pediococcus and Aerococcus. In The Prokaryotes, 2nd edn, vol. 2, pp. 1502-1507. Edited by A. Balows, H. G. Trüper, M. Dworkin, W. Harder \& K.-H. Schleifer. New York: Springer. 